\title{
Erythrasma Revisited: Diagnosis, Differential Diagnoses, and Comprehensive Review of Treatment
}

\author{
Parnia Forouzan ${ }^{1}$, Philip R. Cohen ${ }^{2}$ \\ 1. Dermatology, McGovern Medical School, University of Texas Health Science Center at Houston, Houston, USA 2. \\ Dermatology, San Diego Family Dermatology, National City, USA
}

Corresponding author: Parnia Forouzan, forouzanparnia@gmail.com

\begin{abstract}
Erythrasma is a bacterial infection of the skin typically caused by Corynebacterium minutissimum. This pathogen infects the stratum corneum in warm and wet areas of the skin. Most commonly, the axillary, inguinal, and interdigital regions are affected. A 60-year-old man presented for the examination of a pedunculated lesion on his right proximal thigh. Upon examination of the lesion, adjacent areas of central hypopigmentation and peripheral hyperpigmented scaling were also noted bilaterally in the groin region. Differential diagnoses of candidiasis, dermatophyte infection, erythrasma, pityriasis versicolor, and terra firma-forme dermatosis were considered. Wood lamp examination revealed bright coral-pink fluorescence. Correlation of the clinical examination and the Wood lamp finding established the diagnosis of erythrasma. Twice daily topical $2 \%$ mupirocin ointment therapy led to the resolution of our patient's erythrasma. In this case report, the diagnosis, differential diagnoses, and treatment of erythrasma are reviewed.
\end{abstract}

Categories: Dermatology

Keywords: corynebacterium, diagnosis, differential, erythrasma, infection, lamp, minutissimum, mupirocin, treatment, wood

\section{Introduction}

Erythrasma is a bacterial infection of the skin caused by Corynebacterium minutissimum. C. minutissimum is a gram-positive bacterium most commonly found in warm, moist regions of the skin. Specifically, this pathogen is found in the stratum corneum, the uppermost layers of the epidermis [1]. Erythrasma primarily occurs in skin folds such as in the axillary and inguinal regions. It can also be found on toe webs (interdigital erythrasma) and as a coinfection with Candida albicans or dermatophytes (Epidermophyton, Microsporum, and Trichophyton). The clinical presentation of erythrasma can resemble candidiasis, dermatophyte infections, pityriasis versicolor, and terra firma-forme dermatosis [1, 2].

Review began 09/25/2020 Review ended 09/28/2020 Published 09/30/2020

(c) Copyright 2020

Forouzan et al. This is an open access article distributed under the terms of the Creative Commons Attribution License CC-BY 4.0., which permits unrestricted use, distribution, and reproduction in any medium, provided the original author and source are credited.
A 60-year-old man presented for removal of a pedunculated lesion from his right proximal medial thigh. Clinical examination also revealed adjacent asymptomatic plaques with central hypopigmentation and peripheral hyperpigmented scaling bilaterally in the groin region. Bright coral-pink fluorescence was demonstrated on Wood lamp examination. The Wood lamp finding aided in establishing the diagnosis of erythrasma. The patient's skin infection was successfully treated with twice daily topical application of $2 \%$ mupirocin ointment for six weeks. The diagnosis, differential diagnoses, and management of erythrasma are reviewed.

\section{Case Presentation}

A 60-year-old Hispanic man with Fitzpatrick skin type IV presented for a skin examination; he had light brown skin that minimally burned, and he tanned easily. The patient was concerned about a flesh-colored, pedunculated lesion on his right proximal medial thigh (Figure 1). A skin biopsy was performed, and pathology evaluation diagnosed a benign nevus lipomatosus. 


\section{Cureus}

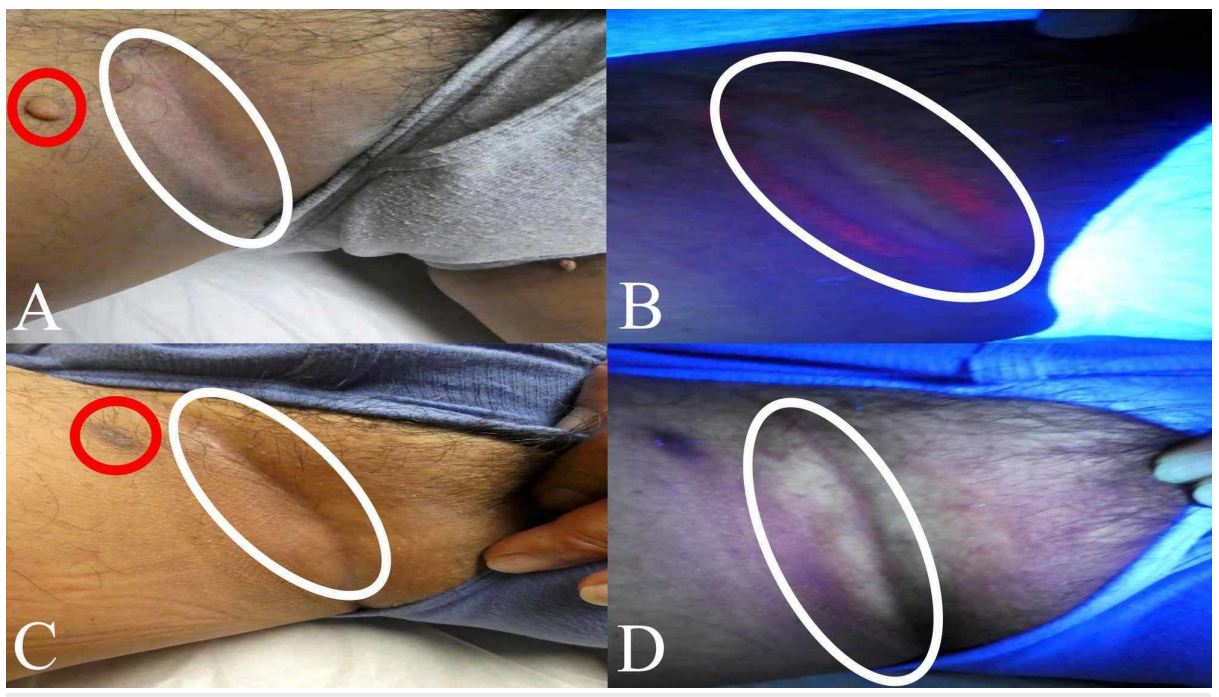

FIGURE 1: Clinical presentation of erythrasma on the right inguinal fold

A 60-year-old man presented for a skin check. He was concerned about a pedunculated lesion on his right proximal thigh (circled in red). Clinical examination also showed a central area of hypopigmentation with peripheral hyperpigmentation and scaling (circled in white) on his right inguinal fold (A). Wood lamp examination revealed a bright coral-pink fluorescence characteristic of erythrasma on the right inguinal fold (B). After six weeks of twice daily topical application of $2 \%$ mupirocin ointment, the biopsy site had healed (circled in red), and his previous lesion of erythrasma (circled in white) had resolved (C). Wood lamp examination was negative for erythrasma on his right inguinal fold; there was no residual coral-pink fluorescence (circled in white) after six weeks of topical $2 \%$ mupirocin ointment therapy (D).

While he was lying on the table with legs apart for examination of the pedunculated lesion on his right thigh, his inguinal fold revealed an area of hypopigmentation surrounded by hyperpigmented scaling (Figure 1). Similar skin changes were also observed on the opposite inguinal fold (Figure 2). Wood lamp examination demonstrated bright coral-pink fluorescence on both inguinal folds (Figures 1-2).

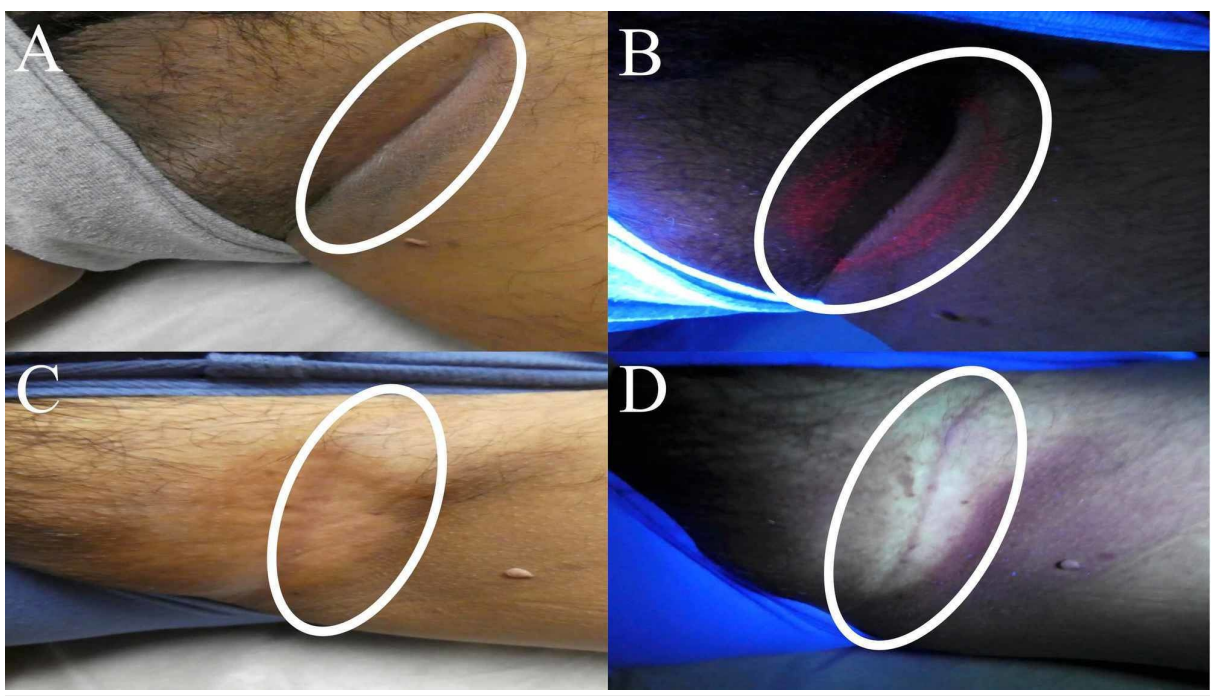

FIGURE 2: Clinical presentation of erythrasma on the left inguinal fold

Clinical examination also showed a central area of hypopigmentation with peripheral hyperpigmentation and scaling (circled in white) on his left inguinal fold (A). Wood lamp examination revealed a bright coral-pink fluorescence characteristic of erythrasma on the left inguinal fold (B). After six weeks of twice daily topical application of $2 \%$ mupirocin ointment, his previous lesion of erythrasma (circled in white) had resolved (C). Wood lamp examination was negative for erythrasma on his left inguinal fold; there was no residual coralpink fluorescence (circled in white) after six weeks of topical $2 \%$ mupirocin ointment therapy (D).

Correlation of the clinical presentation and the Wood lamp examination finding established a diagnosis of erythrasma. The patient was instructed to apply $2 \%$ mupirocin ointment twice daily to the biopsy site and both areas of erythrasma for six weeks. The man returned after six weeks, and his biopsy site was healed. In 
addition, there were no residual skin lesions on his inguinal folds (Figures 1-2). He noted significant clearance after two weeks of therapy but continued his treatment regimen for the full six weeks. Wood lamp examination was also negative for coral-pink fluorescence, confirming clearance of the Corynebacterium minutissimum skin infection.

\section{Discussion}

Erythrasma is a superficial infection of the skin typically caused by Corynebacterium minutissimum. It is more commonly found in diabetic and elderly populations. Indeed, erythrasma makes up $17.6 \%$ of bacterial skin infections in the elderly and $44 \%$ of toe web infections in individuals with diabetes [3, 4].

Corynebacteria are predominantly associated with pitted keratolysis of the feet, especially in those who are frequently barefoot. Corynebacteria can also cause trichobacteriosis of hair shafts in skin folds such as in the axillary region. Erythrasma is the least common of these three Corynebacteria skin infections [5].

The clinical presentation of erythrasma is characterized by asymptomatic lesions often in skin folds and moist areas. Red or brown hyperpigmented patches of skin with scaling and central hypopigmentation are usually observed. The lesions may also be slightly raised [6].

The most common diagnostic test for erythrasma is an examination with a Wood lamp. A Wood lamp is a black light source with a range of light emission between 320 and 400 nanometers. Peak emission occurs at 365 nanometers [7].

The diagnosis of erythrasma can be confirmed through observing coral-pink fluorescence during Wood lamp examination of the affected skin. Porphyrins, predominantly coproporphyrin III, made by Corynebacteria are the origin of this distinguishing fluorescence. Uroporphyrin I is also associated with the fluorescence of Corynebacteria under Wood lamp. Notably, false negatives can occur with Wood lamp examination if the site of the lesion was recently cleansed $[1,4]$.

Albeit rarely performed, a biopsy of the lesion can also establish a diagnosis of erythrasma. It is important for the clinician to alert the pathologist of the suspected condition because the specimen can mimic normalappearing skin after hematoxylin and eosin staining. However, gram, Grocott's methenamine silver, methylene blue, and periodic acid-Schiff (PAS) stains can help identify this bacteria. Biopsy of a lesion of erythrasma and special staining will reveal gram-positive (purple) coccobacilli in the superficial stratum corneum $[5,8]$.

The differential diagnoses of erythrasma, particularly in the groin region, include Candida albicans infection, dermatophyte infection, Malassezia furfur (pityriasis - also referred to as tinea - versicolor) infection, and terra firma-forme dermatosis (Table 1). These conditions can present as hyperpigmented and welldemarcated plaques; however, Wood lamp examination, potassium hydroxide $(\mathrm{KOH})$ preparation findings, and treatment with 70\% isopropyl alcohol can help distinguish between these lesions [1, 4, 6, 9-15]. 


\section{Cureus}

\begin{tabular}{|c|c|c|c|c|c|}
\hline DDx & Candidiasis & $\begin{array}{l}\text { Dermatophyte } \\
\text { infection }\end{array}$ & Erythrasma & Pityriasis (tinea) versicolor & $\begin{array}{l}\text { Terra firma- } \\
\text { forme } \\
\text { dermatosis } \\
\text { (Duncan's dirty } \\
\text { dermatosis) }\end{array}$ \\
\hline Etiology & $\begin{array}{l}\text { Candida albicans } \\
\text { (fungal) }\end{array}$ & $\begin{array}{l}\text { Epidermophyton, } \\
\text { Microsporum, or } \\
\text { Trichophyton (fungal) }\end{array}$ & $\begin{array}{l}\text { Corynebacterium } \\
\text { minutissimum (bacterial) }\end{array}$ & Malassezia furfur (fungal) & $\begin{array}{l}\text { Hyperkeratosis } \\
\text { (no pathogen) }\end{array}$ \\
\hline $\begin{array}{l}\text { Clinical } \\
\text { presentation }\end{array}$ & $\begin{array}{l}\text { Dry, erosive, } \\
\text { erythematous, and } \\
\text { well-demarcated } \\
\text { lesions. }\end{array}$ & $\begin{array}{l}\text { Erythematous and } \\
\text { scaly plaques. }\end{array}$ & $\begin{array}{l}\text { Well-demarcated lesions with } \\
\text { central hypopigmentation } \\
\text { and peripheral } \\
\text { hyperpigmented scaling. }\end{array}$ & $\begin{array}{l}\text { Hyperpigmented and } \\
\text { hypopigmented non-scaly } \\
\text { lesions without sharp } \\
\text { borders. }\end{array}$ & $\begin{array}{l}\text { Dirt-like, } \\
\text { hyperpigmented, } \\
\text { and well- } \\
\text { demarcated } \\
\text { plaques. }\end{array}$ \\
\hline $\begin{array}{l}\text { Most } \\
\text { common } \\
\text { diagnostic } \\
\text { test }\end{array}$ & $\begin{array}{l}\text { KOH preparation } \\
\text { with microscopic } \\
\text { examination reveals } \\
\text { pseudohyphae. }\end{array}$ & $\begin{array}{l}\text { KOH preparation with } \\
\text { microscopic } \\
\text { examination reveals } \\
\text { septate hyphae. }^{a}\end{array}$ & $\begin{array}{l}\text { Coral-pink fluorescence with } \\
\text { Wood lamp examination. }\end{array}$ & $\begin{array}{l}\text { KOH preparation with } \\
\text { microscopic examination } \\
\text { shows hyphae and spores. }\end{array}$ & $\begin{array}{l}\text { Removal of } \\
\text { lesions with } 70 \% \\
\text { isopropyl alcohol. }\end{array}$ \\
\hline Histology & $\begin{array}{l}\text { Pseudohyphae in the } \\
\text { stratum corneum. }\end{array}$ & $\begin{array}{l}\text { Septate hyphae in the } \\
\text { stratum corneum. }\end{array}$ & $\begin{array}{l}\text { Gram-positive coccobacilli in } \\
\text { the stratum corneum. }\end{array}$ & $\begin{array}{l}\text { Hyphae and clusters of } \\
\text { spores in the stratum } \\
\text { corneum (described as } \\
\text { "spaghetti and meatballs"). }\end{array}$ & $\begin{array}{l}\text { Hyperpigmented } \\
\text { basal layer and } \\
\text { compact } \\
\text { orthokeratosis. }\end{array}$ \\
\hline References & {$[6,9]$} & {$[9-10]$} & {$[1,4]$} & {$[6,9-12]$} & [13-15] \\
\hline
\end{tabular}

\section{TABLE 1: Differential diagnoses of erythrasma}

$\mathrm{DDx}$ - differential diagnosis; $\mathrm{KOH}$ - potassium hydroxide

a Microspora will also fluoresce green under Wood lamp.

b Malassezia furfur will also fluoresce yellow-gold under Wood lamp.

Candidiasis is a fungal infection that can be identified using $\mathrm{KOH}$ preparation. If pseudohyphae are observed with $\mathrm{KOH}$ preparation, infection with C. albicans is most likely. In addition, Wood lamp examination will be negative for fluorescence $[6,9]$.

Dermatophyte infection is a fungal infection with either Epidermophyton, Microsporum, or Trichophyton. $\mathrm{KOH}$ preparation can confirm the diagnosis of a dermatophyte infection if septate hyphae are present in the stratum corneum. Some of these fungi can also fluoresce under Wood lamp [9-10].

Dermatophyte infections of hair, such as tinea capitis, may have a positive Wood lamp examination for ectothrix infection. In ectothrix infections, fungal organisms are located outside the hair shaft and allow for detection with Wood lamp examination. For example, Microsporum can fluoresce green [9-10].

Bacterial infection with Malassezia furfur is called pityriasis versicolor or tinea versicolor. Pityriasis versicolor can demonstrate yellow-gold fluorescence with Wood lamp. Histological examination may also help distinguish this pathogen and will reveal hyphae and small spores in the stratum corneum described as "spaghetti and meatballs". However, the diagnosis is usually confirmed by examination of a KOH preparation of the lesion [6, 9-12].

Terra firma-forme dermatosis (Duncan's dirty dermatosis) is unique among the differential diagnoses of erythrasma because there is no pathogen associated with this condition. Therefore, negative Wood lamp and $\mathrm{KOH}$ examinations can suggest terra firma-forme dermatosis. Histologic findings include hyperpigmentation in the basal layer and compact orthokeratosis [13-15].

Terra firma-forme dermatosis can be diagnosed by rubbing 70\% isopropyl alcohol on the areas of hyperpigmentation. If the hyperpigmentation is removed, terra firma-forme dermatosis is the likely diagnosis. Identical to the diagnostic procedure, the treatment also involves the removal of all lesions with 70\% isopropyl alcohol [13-15]. 
Several treatment options are available for erythrasma. Systemic oral treatment options include clarithromycin, erythromycin, and tetracycline (Table 2) $[8,16,17]$. Topical treatment options for erythrasma include clindamycin, fusidic acid, mupirocin, and Whitfield's ointment (Table 3) [1, 16-20].

\begin{tabular}{|c|c|c|c|c|c|c|}
\hline Tx & \multicolumn{2}{|l|}{ Clarithromycin } & \multicolumn{2}{|l|}{ Erythromycin } & \multicolumn{2}{|c|}{ Tetracycline } \\
\hline Dose & \multicolumn{2}{|l|}{$1 \mathrm{~g}$ single dose. } & \multicolumn{2}{|c|}{250 mg QID for 14 days. } & \multicolumn{2}{|c|}{250 mg QID for 14 days. } \\
\hline MOA & \multicolumn{2}{|c|}{$\begin{array}{l}\text { Macrolide antibiotic that inhibits } \\
\text { protein synthesis by binding the } 50 \mathrm{~S} \\
\text { ribosomal subunit. }\end{array}$} & \multicolumn{2}{|c|}{$\begin{array}{l}\text { Macrolide antibiotic that inhibits protein } \\
\text { synthesis by binding the } 50 \mathrm{~S} \text { ribosomal } \\
\text { subunit. }\end{array}$} & \multicolumn{2}{|c|}{$\begin{array}{l}\text { Antibiotic that inhibits protein } \\
\text { synthesis by binding the } 30 \mathrm{~S} \\
\text { ribosomal subunit. }\end{array}$} \\
\hline Benefits & \multicolumn{2}{|c|}{$\begin{array}{l}\text { Effective, fewer Gl adverse events } \\
\text { compared to erythromycin, and single- } \\
\text { dose treatment (encourages } \\
\text { compliance). }\end{array}$} & \multicolumn{2}{|c|}{$\begin{array}{l}\text { Effective and safer than } \\
\text { chloramphenicol. }^{\mathrm{a}}\end{array}$} & \multicolumn{2}{|c|}{$\begin{array}{l}\text { Effective and safer than } \\
\text { chloramphenicol. }^{\text {a }}\end{array}$} \\
\hline $\begin{array}{l}\text { Possible } \\
\text { adverse } \\
\text { effects }\end{array}$ & \multicolumn{2}{|c|}{$\begin{array}{l}\text { Abdominal cramps, allergic reaction, } \\
\text { dyspepsia, hearing loss, metallic taste } \\
\text { in mouth, neutropenia, and ventricular } \\
\text { arrhythmias. }\end{array}$} & \multicolumn{2}{|c|}{$\begin{array}{l}\text { Abdominal pain, allergic reaction, } \\
\text { cholestatic hepatitis, dyspepsia, hearing } \\
\text { loss, Steven-Johnson syndrome, and } \\
\text { ventricular arrhythmias. }\end{array}$} & \multicolumn{2}{|c|}{$\begin{array}{l}\text { Allergic reaction, esophagitis, } \\
\text { hemolytic anemia, phototoxic } \\
\text { reaction, renal toxicity, and tooth } \\
\text { discoloration. }\end{array}$} \\
\hline References & \multicolumn{2}{|l|}{$[8,16,17]$} & \multicolumn{2}{|l|}{$[8,16,17]$} & \multicolumn{2}{|c|}{$[8,17]$} \\
\hline \multicolumn{7}{|c|}{$\begin{array}{l}\text { TABLE 2: Systemic treatments for erythrasma } \\
\text { g - gram; mg - milligrams; GI - gastrointestinal; MOA - mechanism of action; QID - four times per day; Tx - treatment }\end{array}$} \\
\hline \multicolumn{7}{|c|}{$\begin{array}{l}\text { a Chloramphenicol is an antibiotic that was previously used to treat erythrasma. It inhibits peptidyl transferase, disrupting bacterial protein synthesis. } \\
\text { An oral } 250 \text { mg dosage four times daily can lead to the resolution of erythrasma in } 14 \text { days. However, the side effects, which include aplastic } \\
\text { anemia, bone marrow suppression, and encephalopathy, deter from its use currently [17]. }\end{array}$} \\
\hline $\mathbf{T x}^{\mathrm{a}}$ & $2 \%$ clindamycin & $2 \%$ fus & idic acid & $2 \%$ mupirocin & & Whitfield's ointment $^{\mathrm{b}}$ \\
\hline Dosage & $\begin{array}{l}\text { Three times daily application } \\
\text { for seven days. }\end{array}$ & $\begin{array}{l}\text { Twice } \mathrm{c} \\
\text { for } 14 \mathrm{~d}\end{array}$ & $\begin{array}{l}\text { laily application } \\
\text { lays. }\end{array}$ & $\begin{array}{l}\text { Twice daily application fo } \\
\text { to } 28 \text { days. }\end{array}$ & & $\begin{array}{l}\text { Twice daily application for } \\
\text { seven days. }\end{array}$ \\
\hline MOA & $\begin{array}{l}\text { Antibiotic that disrupts protein } \\
\text { synthesis by binding the } 50 \mathrm{~S} \\
\text { ribosomal subunit. }\end{array}$ & $\begin{array}{l}\text { Antibio } \\
\text { with pro } \\
\text { by bind }\end{array}$ & $\begin{array}{l}\text { tic that interferes } \\
\text { otein synthesis } \\
\text { ing EF-G. }\end{array}$ & $\begin{array}{l}\text { Antibiotic that inhibits pre } \\
\text { synthesis by binding } \\
\text { isoleucyl-tRNA synthetas }\end{array}$ & tein & $\begin{array}{l}\text { Benzoic acid: inhibits } \\
\text { bacterial growth. Salicylic } \\
\text { acid: keratolytic agent. }\end{array}$ \\
\hline $\begin{array}{l}\text { Possible } \\
\text { adverse } \\
\text { effects }\end{array}$ & $\begin{array}{l}\text { Colitis, neutropenia, } \\
\text { polyarthritis. }^{c}\end{array}$ & $\begin{array}{l}\text { Allergic } \\
\text { ulcerati }\end{array}$ & $\begin{array}{l}\text { reaction, } \\
\text { on. }\end{array}$ & None reported. & & $\begin{array}{l}\text { Allergic reaction, } \\
\text { ulceration. }\end{array}$ \\
\hline References & [17] & {$[16,17$} & , 19] & {$[1,20]$} & & [17] \\
\hline
\end{tabular}

\section{TABLE 3: Topical treatments for erythrasma}

EF-G: elongation factor G; g - grams; mg - milligrams; MOA - mechanism of action; tRNA - transfer ribonucleic acid; Tx - treatment

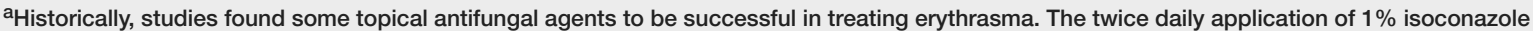
nitrate and $0.1 \%$ diflucortolone valerate for five days was used as therapy with no reported side effects. Isoconazole (antifungal) inhibits ergosterol synthesis of the fungal cell membrane, and diflucortolone valerate (corticosteroid) dampens the inflammatory response. However, antifungals are currently not used to treat erythrasma [18].

bWhitfield's ointment consists of $12 \%$ benzoic acid and $6 \%$ salicylic acid.

${ }^{\mathrm{C}}$ These side effects are uncommon with topical treatment yet have been noted with systemic therapy.

Clarithromycin and erythromycin are macrolide antibiotics. Macrolides inhibit bacterial protein synthesis through reversibly binding the $50 \mathrm{~S}$ bacterial ribosomal subunit. Oral treatment with $250 \mathrm{mg}$ erythromycin four times daily can lead to the clearance of erythrasma in 14 days. A single one-gram dosage of 
clarithromycin is also effective; however, macrolides may be associated with gastrointestinal adverse events such as an upset stomach. Clarithromycin has greater bioavailability and a longer half-life compared to erythromycin. The milder gastric effects and single-dose treatment of clarithromycin can encourage better compliance and greater patient satisfaction $[4,8,16,17]$.

Tetracycline is a bacteriostatic agent that reversibly binds the $30 \mathrm{~S}$ bacterial ribosomal subunit. It is usually well-tolerated but is associated with photosensitivity during therapy. In addition, it cannot be used in pregnant women and children because of tooth discoloration [8, 17].

Topical therapies for erythrasma are usually preferred over oral therapy because there are fewer and less severe adverse events associated with topical treatment. In fact, one study found topical fusidic acid cream to be more effective than oral clarithromycin and erythromycin in treating erythrasma. In addition, greater patient compliance has been observed with topical therapy compared to systemic therapy $[8,16]$.

Clindamycin is a bacteriostatic antibiotic that reversibly binds the 50S ribosomal subunit, disrupting protein synthesis. The topical application of this agent three times per day for one week can lead to complete eradication of erythrasma with no recurrence. Although systemic clindamycin therapy can be associated with colitis and neutropenia, these adverse events are rarely observed with topical treatment [17].

Fusidic acid is a bacteriostatic antibiotic that interferes with protein synthesis by binding elongation factor $\mathrm{G}$ involved in peptide elongation. Application of $2 \%$ fusidic acid cream twice daily for two weeks led to complete resolution of erythrasma for $96.8 \%$ of patients. Allergic reactions and ulceration were noted in some individuals with this therapy $[16,17,19]$.

More recently, treatment with topical 2\% mupirocin ointment has been shown to be effective in treating erythrasma. Mupirocin is an antibiotic that inhibits protein synthesis by binding isoleucyl-tRNA synthetase. Mupirocin ointment, which can be used to promote healing of a cryotherapy site in patients who have received treatment of actinic keratoses, can also be used to treat the infection with Corynebacterium [1, 20].

Nine men from the age of 32 years to 80 years were treated with topical $2 \%$ mupirocin ointment for two to four weeks. All patients observed the resolution of their erythrasma and had no recurrence at follow-up visits. In addition, there were no significant side effects associated with this treatment modality. The authors suggested that $2 \%$ mupirocin ointment be considered as first-line therapy for erythrasma [1].

Whitfield's ointment contains $12 \%$ benzoic acid and $6 \%$ salicylic acid. These agents work together to inhibit bacterial growth and encourage sloughing off of skin cells (keratolysis). One study found twice daily application of Whitfield's ointment for seven days as effective in treating erythrasma as $250 \mathrm{mg}$ oral erythromycin or tetracycline taken four times per day for seven days [17].

We postulate that over-the-counter agents such as bacitracin, neomycin, and polymyxin may also be used to treat erythrasma. This hypothesis remains unexplored in studies. However, it could be a cost-effective and easily accessible topical treatment option for erythrasma.

\section{Conclusions}

Erythrasma is a bacterial infection caused by Corynebacterium minutissimum. The clinical presentation and bright coral-pink fluorescence observed with Wood lamp examination can help to establish a diagnosis of erythrasma. Systemic treatments as well as topical treatments can be effective in treating this superficial skin infection. Topical therapy is routinely pursued due to fewer side effects and greater compliance compared to systemic therapies. Our patient was treated with topical $2 \%$ mupirocin ointment for six weeks and had noted nearly complete resolution within two weeks.

\section{Additional Information \\ Disclosures}

Human subjects: Consent was obtained by all participants in this study. Conflicts of interest: In compliance with the ICMJE uniform disclosure form, all authors declare the following: Payment/services info: All authors have declared that no financial support was received from any organization for the submitted work. Financial relationships: Philip R. Cohen, MD declare(s) personal fees from ParaPRO. Dr. Cohen is a paid consultant for ParaPRO. Other relationships: All authors have declared that there are no other relationships or activities that could appear to have influenced the submitted work.

\section{References}

1. Greywal T, Cohen PR: Erythrasma: a report of nine men successfully managed with mupirocin $2 \%$ ointment monotherapy. Dermatol Online J. 2017, 23:13030/qt9zh116s1.

2. Holdiness MR: Erythrasma and common bacterial skin infections. Am Fam Physician. 2003, 67:254.

3. Polat M, İlhan MN: Dermatological complaints of the elderly attending a dermatology outpatient clinic in 
Turkey: a prospective study over a one-year period. Acta Dermatovenerol Croat. 2015, 23:277-281.

4. Thiyanaratnam J, Cohen PR: What caused this groin plaque?. Dermatologist. 2009, 17:46-50.

5. Blaise G, Nikkels AF, Hermanns-Lê T, Nikkels-Tassoudji N, Piérard GE: Corynebacterium-associated skin infections. Int J Dermatol. 2008, 47:884-890. 10.1111/j.1365-4632.2008.03773.x

6. Aridogan IA, Izol V, Ilkit M: Superficial fungal infections of the male genitalia: a review . Crit Rev Microbiol. 2011, 37:237-244. 10.3109/1040841X.2011.572862

7. Bae JM, Lee RW: 365-nm narrowband Wood's lamp for vitiligo and hypopigmentation disorders . J Am Acad Dermatol. 2020, 83:e283-e284. 10.1016/j.jaad.2019.08.064

8. Chodkiewicz HM, Cohen PR: Erythrasma: successful treatment after single-dose clarithromycin. Int J Dermatol. 2013, 52:516-518. 10.1111/j.1365-4632.2011.05005.x

9. Nenoff P, Krüger C, Schaller J, Ginter-Hanselmayer G, Schulte-Beerbühl R, Tietz HJ: Mycology - an update part 2: dermatomycoses: clinical picture and diagnostics. J Dtsch Dermatol Ges. 2014, 12:749-777. $10.1111 /$ ddg. 12420

10. Klatte JL, van der Beek N, Kemperman PM: 100 years of Wood's lamp revised . J Eur Acad Dermatol Venereol. 2015, 29:842-847. 10.1111/jdv.12860

11. Cohen PR, Erickson C, Calame A: Malassezia (pityrosporum) folliculitis incognito: malessezia-associated folliculitis masked by topical corticosteroid therapy. Cureus. 2020, 12:e6531. 10.7759/cureus.6531

12. Aste N, Pau M, Aste N: Pityriasis versicolor on the groin mimicking erythrasma. Mycoses. 2004, 47:249-251. 10.1111/j.1439-0507.2004.00977.x

13. Cohen, PR: Terra firma-forme dermatosis of the inguinal fold: Duncan's dirty dermatosis mimicking groin dermatoses. Open J Clin Med Case Rep. 2015, 1:1022.

14. Greywal T, Cohen PR: Terra firma-forme dermatosis: a report of ten individuals with Duncan's dirty dermatosis and literature review. Dermatol Pract Concept. 2015, 5:29-33. 10.5826/dpc.0503a08

15. Greywal T, Cohen PR: Non-invasive methods to establish the diagnosis of terra firma-forme dermatosis: the SMART (skin modified by alcohol rubbing test) evaluation and dermoscopy. Dermatol Online J. 2016, 22:13030/qt7jk6k6d9.

16. Avci O, Tanyildizi T, Kusku E: A comparison between the effectiveness of erythromycin, single-dose clarithromycin and topical fusidic acid in the treatment of erythrasma. J Dermatolog Treat. 2013, 24:70-74. 10.3109/09546634.2011.594870

17. Holdiness MR: Management of cutaneous erythrasma. Drugs. 2002, 62:1131-1141. 10.2165/00003495200262080-00002

18. Piergiorgio M: Effective treatment of erythrasma-associated inflammation and pruritus with isoconazole nitrate and diflucortolone valerate combination therapy. Mycoses. 2013, 56:38-40. 10.1111/myc.12046

19. Borg A, Holm M, Shiroyama I, et al.: Fusidic acid targets elongation factor $\mathrm{G}$ in several stages of translocation on the bacterial ribosome. J Biol Chem. 2015, 290:3440-3454. 10.1074/jbc.M114.611608

20. Parenti MA, Hatfield SM, Leyden JJ: Mupirocin: a topical antibiotic with a unique structure and mechanism of action. Clin Pharm. 1987, 6:761-770. 